\title{
Haematological and blood biochemical alterations associated with respiratory disease in calves
}

\author{
Helena Šoltésová, Veronika Nagyová, Csilla Tóthová, Oskar Nagy \\ University of Veterinary Medicine and Pharmacy, Clinic for Ruminants, Košice, Slovak Republic
}

Received January 9, 2015

Accepted May 13, 2015

\begin{abstract}
Respiratory diseases of cattle, particularly in young animals, represent the most important health and economic problem of cattle rearing. The aim of the present study was to evaluate the changes of selected blood indices in 25 calves aged 2-9 months suffering from etiologically undifferentiated chronic respiratory diseases. Blood samples were analysed for haematological indices and selected serum biochemistry variables. The results found in sick animals were compared with results from 25 healthy animals of the same age, housing and feeding system. Significant differences in means between the groups of clinically healthy and sick calves were found in 13 out of 24 evaluated indicators. In sick animals we found significantly higher mean concentrations of haemoglobin and total number of white blood cells $(P<0.05$ and $P<0.01$, respectively), as well as higher mean activity of AST and LDH $(P<0.01)$, concentrations of total proteins and total immunoglobulins $(P<0.001)$. Significantly lower mean values were recorded in the serum concentrations of albumin, creatinine and glucose $(P<0.001)$, as well as in the concentration of $\mathrm{Mg}(P<0.01), \mathrm{P}(P<0.001), \mathrm{Fe}$ and $\mathrm{Zn}(P<0.05)$. The presented results suggest the effect of respiratory diseases in calves on several changes of haematological and selected serum biochemical indicators. They indicate that respiratory diseases did not lead only to direct disturbance of gas exchange and acid-base balance, but they also indirectly affect some other variables of blood biochemistry.
\end{abstract}

Bovine, bronchopneumonia, blood, haematology, clinical biochemistry

Respiratory diseases are the most prevalent disease in young cattle. Prophylactic measures, high cost of therapeutic interventions, mortality, reduced growth performance due to bovine respiratory disease (BRD), and irreversible pulmonary lesions lead to considerable economic losses (Coghe et al. 1999). Respiratory diseases in calves are associated with a wide scale of pathological findings in the lung parenchyma, as well as in the respiratory pathways. Although various forms of calf respiratory diseases are known, their clinical manifestation is frequently less differentiated. Despite the great variety of combinations of pathogens that have been implicated as causes of this disease, the clinical entity of most manifested is bronchopneumonia (Lekeux 1995). Cattle typically face two primary problems that contribute to a high incidence of BRD. First, stress associated with weaning and transportation has a negative effect on the immune system. Second, this stress typically occurs when the animal is exposed to a variety of infectious agents as a result of marketing (transporting) management procedures. Nutrition can interact with these two primary factors, most likely as a result of preweaning nutritional deficiencies or through decreased feed intake associated with stress. Low feed and thereby nutrient intake makes correction of nutritional deficiencies difficult, which could further compromise immune function and potentially increase susceptibility to infection (Cole 1996).

Respiratory diseases lead to various degrees of hypoxaemia with possible subsequent tissue hypoxia. Other possible consequences include accompanying hypercapnia and respiratory acidosis (Wall 2001). Hypoxaemia and hypercapnia are the direct consequence of disturbances in basic respiratory functions, namely gas exchange. In calves suffering

Address for correspondence:

MVDr. Helena Šoltésová

Clinic for Ruminants, University of Veterinary Medicine and Pharmacy

Komenského 73, 04181 Košice, Slovak Republic

\author{
Phone: +421915326885 \\ Fax: +421556711674 \\ E-mail: helasoltes@gmail.com \\ http://actavet.vfu.cz/
}


from the respiratory syndrome, data published indicate various degrees of changes in blood gases and disturbances of acid base balance (Collie 1992). However, respiratory diseases not only lead to direct disturbance of gas exchange, but they could affect some other constituents of blood such as lactate and lactate dehydrogenase and its isoenzyme pattern (Coghe et al. 2000; Nagy et al. 2006, 2013). Cardiovascular, neurological, and metabolic consequences are reported in human beings and experimental animal models with respiratory acidosis. However, there are very scarce data about other possible endocrine, metabolic and haematological changes associated with bronchopneumonia in calves (Schulz et al. 1987; Blum et al. 1996; Bednarek et al. 1998; Hanzlicek et al. 2010; Fraser et al. 2014). These may occur due to decreased food intake and disturbed metabolism of nutrients (energy, protein, minerals, vitamins, etc.) required for growth and development. In the affected animals, this is manifested by a subsequent decrease in growth intensity, reduced rate of weight gains, additional days on feed and negative impact on carcass quality with substantial negative effect on farm production and economy (Wittum et al. 1996; Gardner et al. 1999). Recently, there are some results indicating the association of respiratory disease in calves with changes in serum protein pattern and acute phase protein concentrations as well (Tothova et al. 2012, 2013).

The objective of this study was to determine the association between aetiologically undifferentiated chronic respiratory diseases and changes of haematological variables and selected blood biochemistry variables in calves and thereby widen the knowledge of the clinical chemistry of this serious health problem.

\section{Materials and Methods}

The study included 25 calves exhibiting clinical signs of chronic bronchopneumonia of various degrees. The calves were of the Slovak Pied cattle, Holstein cattle, or their crossbreeds. The age of the calves ranged from two to nine months, and their body weight was $65-249 \mathrm{~kg}$. The evaluated animals were housed and treated at the University dairy farm or were submitted for the treatment to the Clinic for Ruminants by private veterinarians from this farm. At the farm and after the arrival to the clinic, all calves were thoroughly examined using standard clinical examination procedures focused on the case history, examination of the general health state (body temperature, food intake, behaviour, body condition), and then with a special focus on the respiratory system. The respiratory system was examined by visual inspection (breathing rate, nasal discharges, type of breathing, dyspnoea, dry or wet spontaneous cough) and auscultation (increased or decreased loudness of the breathing sounds, bronchial sounds, abnormal breath sounds - most commonly crackles, in some animals also wheezes and signs of laboured breathing with open mouth). We included in the study calves manifesting clinical signs of the disease for more than two weeks despite antimicrobial, antiinflammatory, and supportive therapy. The evaluated animals did not show any pathological lesions on the other organ systems. To analyse the effect of respiratory diseases on the evaluated indicators, we also included 25 clinically healthy calves at the age of two to nine months and body weight of $61-242 \mathrm{~kg}$ into the study, randomly selected as the control group from the same farms as the sick calves sent to the clinic. They were of the same breed and in good general health without any obvious signs of diseases.

Blood samples for analyses of the evaluated indicators from both healthy and sick animals were taken once after the clinical examination by direct puncture of vena jugularis. Blood was collected from the sick animals more than $24 \mathrm{~h}$ after transportation at the clinic, when clinical symptoms were apparent. Blood from the control group of calves was collected at the farms. Blood for haematological examination was collected into plastic tubes with $\mathrm{K}_{3}$ EDTA as anticoagulant and for serum biochemistry into tubes without anticoagulant and with serum cloth activator (Meus, Piove di Sacco, Italy). The separated serum was stored at $-20{ }^{\circ} \mathrm{C}$ until analysed. Evaluated haematological indices included total red blood cell count (RBC, T/l), haemoglobin concentration ( Hb, g/dl), total white blood cell count (WBC, G/1), packed cell volume (PCV, 1/1), and mean corpuscular volume (MCV, f/l). The indicators of haematological profile were analysed by an automatic haematological analyser $\mathrm{ABC}$-vet (Horiba ABX, France). Concentrations of serum total proteins (TP, g/l), albumin (Alb, g/l), urea (U, mmol/l ), creatinin (Creat, $\mathrm{mmol} / \mathrm{l})$, glucose (Glu, $\mathrm{mmol} / \mathrm{l})$, phosphorus $(\mathrm{P}, \mathrm{mmol} / \mathrm{l})$ and chlorides $(\mathrm{Cl}, \mathrm{mmol} / \mathrm{l})$, activity of aspartate aminotrasferase (AST, $\mu \mathrm{kat} / \mathrm{l})$, gamma glutamyltransferase (GGT, $\mu \mathrm{kat} / \mathrm{l})$, creatine phosphokinase (CK, $\mu \mathrm{kat} / \mathrm{l})$, lactate dehydrogenase ( $\mathrm{LDH}, \mu \mathrm{kat} / \mathrm{l})$ were assessed on automated biochemical analyser Alizé (Lisabio, France) using commercial diagnostic kits (Randox, UK). Serum concentrations of calcium (Ca, mmol/l), magnesium (Mg, $\mathrm{mmol} / \mathrm{l})$, sodium $(\mathrm{Na}, \mathrm{mmol} / \mathrm{l})$, potassium $(\mathrm{K}, \mathrm{mmol} / \mathrm{l})$, zinc $(\mathrm{Zn}, \mu \mathrm{mol} / \mathrm{l})$ and iron $(\mathrm{Fe}, \mu \mathrm{mol} / \mathrm{l})$ were analysed by atomic absorption spectrophotometer (AAnalyst 100, Perkin Elmer). Total immunoglobulins (TIg, U ZST) were analysed by spectrophotometric turbidimetric method (zinc-sulphate test) and concentrations of total bilirubin (TBil, $\mu \mathrm{mol} / \mathrm{l}$ ) were analysed by spectrophotometric method (Specol 211, Carl Zeiss Jena). 
Arithmetic means (x) and standard deviations (SD) for each evaluated variable and group of calves were calculated using the descriptive statistical procedures. Student's non paired $t$-test was used for comparison of the significances of the differences in means $(P$ value $)$ between the groups of calves. All statistical analyses were performed using the computer programme GraphPad Prism V5.02 (GraphPad Software Inc., California, USA).

\section{Results}

The results in the two groups of calves are presented in Tables 1-3 including the means, standard deviations, and significances of differences between the groups.

Table 1. Results of the evaluation of the haematological profile in healthy calves and calves suffering from respiratory diseases (mean $\pm \mathrm{SD})$.

\begin{tabular}{lcccc}
\hline \multirow{2}{*}{ Parameter } & \multicolumn{2}{c}{ Group of calves } & \multirow{2}{*}{$P$ value } & Reference values* \\
\cline { 2 - 3 } & Healthy & Sick & & \\
\hline $\mathrm{Hb}(\mathrm{g} / \mathrm{dl})$ & $9.8 \pm 1.2$ & $11.0 \pm 1.7$ & $<0.05$ & $9.3-11.7$ \\
$\mathrm{RBC}(\mathrm{T} / \mathrm{l})$ & $8.8 \pm 1.1$ & $9.5 \pm 1.6$ & n.s. & $5.1-7.9$ \\
$\mathrm{WBC}(\mathrm{G} / \mathrm{l})$ & $10.0 \pm 3.2$ & $16.0 \pm 11.0$ & $<0.01$ & $6.0-10.0$ \\
$\mathrm{PCV}(\mathrm{l} / \mathrm{l})$ & $0.3 \pm 0.05$ & $0.3 \pm 0.06$ & n.s. & $0.3-0.4$ \\
$\mathrm{MCV}(\mathrm{f} / \mathrm{l})$ & $34.0 \pm 2.8$ & $34.0 \pm 5.0$ & n.s. & $42.4-74.4$ \\
\hline
\end{tabular}

* Reference values used at the Clinical Laboratory of the Clinic for Ruminats (Slanina et al. 1992)

$\mathrm{Hb}$ - haemoglobin; RBC - red blood cell; WBC - white blood cell; PCV - packed cell volume; MCV - mean cell volume

$P$ - significance of differences between groups of calves; n.s. - non-significant

Table 2. Results of the evaluation of selected indices of the biochemical profile in blood serum of healthy calves and calves with chronic respiratory diseases (mean $\pm \mathrm{SD}$ ).

\begin{tabular}{|c|c|c|c|c|}
\hline \multirow{2}{*}{ Indicator } & \multicolumn{2}{|c|}{ Group of calves } & \multirow{2}{*}{$P$ value } & \multirow{2}{*}{ Reference values* } \\
\hline & Healthy & Sick & & \\
\hline AST $(\mu \mathrm{kat} / \mathrm{l})$ & $1.1 \pm 0.4$ & $2.1 \pm 1.4$ & $<0.01$ & $1.3-2.2$ \\
\hline GGT ( $\mu \mathrm{kat} / \mathrm{l})$ & $0.6 \pm 0.4$ & $0.6 \pm 0.8$ & n.s. & $0.1-0.6$ \\
\hline CK $(\mu \mathrm{kat} / \mathrm{l})$ & $3.9 \pm 1.4$ & $4.5 \pm 2.8$ & n.s. & $0-5.8$ \\
\hline LDH (ukatl/1) & $34.0 \pm 8.9$ & $60.0 \pm 38.0$ & $<0.01$ & $11-45$ \\
\hline TIg (U ZST) & $22.0 \pm 4.6$ & $30.0 \pm 7.3$ & $<0.001$ & $18-26$ \\
\hline $\mathrm{TP}(\mathrm{g} / \mathrm{l})$ & $63.0 \pm 4.1$ & $75.0 \pm 13.0$ & $<0.001$ & $50-70$ \\
\hline $\mathrm{Alb}(\mathrm{g} / \mathrm{l})$ & $37.0 \pm 2.0$ & $32.0 \pm 5.0$ & $<0.001$ & $30-45$ \\
\hline Creat (mmol/l) & $90.0 \pm 17.0$ & $66.0 \pm 12.0$ & $<0.001$ & $<177$ \\
\hline Urea (mmol/l) & $3.2 \pm 1.3$ & $3.1 \pm 1.6$ & n.s. & $2.0-5.5$ \\
\hline Glu (mmol/l) & $5.9 \pm 1.0$ & $4.2 \pm 0.9$ & $<0.001$ & $5.5-8.3$ \\
\hline TBil $(\mu \mathrm{mol} / \mathrm{l})$ & $5.1 \pm 1.8$ & $7.1 \pm 5.1$ & n.s. & $<7.5$ \\
\hline
\end{tabular}

* Reference values used at the Clinical Laboratory of the Clinic for Ruminats (Slanina et al. 1992)

$P$ - significance of the differences between the groups of calves; n.s. - non-significant

Significant differences in the means between the groups of clinically healthy and sick calves were found in 13 of the 24 evaluated indices. In haematological profile (Table 1) the concentrations of haemoglobin and total number of white blood cells showed significantly higher mean values in sick animals $(P<0.05$ and $P<0.01$, respectively). Higher mean value was also found in sick calves in the total red blood cell count. The means of PCV and MCV were similar in both groups of calves. 
Among the evaluated blood serum biochemistry indices (Table 2) significant differences in means between the groups of calves were found in the activity of AST and LDH $(P<0.01)$, concentrations of total proteins, total immunoglobulins, albumin, creatinine and glucose $(P<0.001)$. In calves with respiratory diseases the means of AST, LDH, TP and TIg were higher, whereas the mean values of albumin, creatinine and glucose were lower. Non-significantly higher means in sick calves were also recorded in the activity of $\mathrm{CK}$ and concentration of total bilirubin. The lowest mean differences were evident for the activity of GGT and concentration of urea. Analysis of the evaluated minerals (Table 3 ) showed significantly lower mean values in the serum concentrations of $\mathrm{Mg}(P<0.01), \mathrm{P}$ $(P<0.001)$, Fe and $\mathrm{Zn}(P<0.05)$ in sick calves. No significant differences in the means were evident for serum concentrations of $\mathrm{Ca}, \mathrm{Na}, \mathrm{K}$ and $\mathrm{Cl}$; however, all of the mean concentrations of these indices were lower in sick calves.

Table 3. Results of the evaluation of selected indices of the mineral profile in blood serum of healthy calves and calves with chronic respiratory diseases (mean $\pm \mathrm{SD})$.

\begin{tabular}{|c|c|c|c|c|}
\hline \multirow{2}{*}{ Indicator } & \multicolumn{2}{|c|}{ Group of calves } & \multirow{2}{*}{$P$ value } & \multirow{2}{*}{ Reference values* } \\
\hline & Healthy & Sick & & \\
\hline $\mathrm{Ca}(\mathrm{mmol} / \mathrm{l})$ & $2.70 \pm 0.27$ & $2.50 \pm 0.34$ & n.s. & $2.25-2.8$ \\
\hline $\mathrm{Mg}(\mathrm{mmol} / \mathrm{l})$ & $0.90 \pm 0.1$ & $0.81 \pm 0.12$ & $<0.01$ & $0.78-1.1$ \\
\hline $\mathrm{P}(\mathrm{mmol} / \mathrm{l})$ & $2.70 \pm 0.29$ & $2.0 \pm 0.33$ & $<0.001$ & $1.6-2.3$ \\
\hline $\mathrm{Na}(\mathrm{mmol} / \mathrm{l})$ & $145.0 \pm 6.1$ & $142.0 \pm 5.9$ & n.s. & $136-150$ \\
\hline $\mathrm{K}(\mathrm{mmol} / \mathrm{l})$ & $4.9 \pm 0.5$ & $4.8 \pm 0.45$ & n.s. & $4.0-5.5$ \\
\hline $\mathrm{Cl}(\mathrm{mmol} / \mathrm{l})$ & $101.0 \pm 4.3$ & $98.0 \pm 4.4$ & n.s. & $96-110$ \\
\hline $\mathrm{Fe}(\mu \mathrm{mol} / \mathrm{l})$ & $21.0 \pm 7.2$ & $17.0 \pm 4.3$ & $<0.05$ & $16-26$ \\
\hline $\mathrm{Zn}(\mu \mathrm{mol} / \mathrm{l})$ & $17.0 \pm 7.8$ & $12.0 \pm 3.1$ & $<0.05$ & $12.2-24$ \\
\hline
\end{tabular}

* Reference values used at the Clinical Laboratory of the Clinic for Ruminats (Slanina et al. 1992)

$P$ - significance of the differences between the groups of calves; n.s. - non-significant

\section{Discussion}

Inflammation caused by the bovine respiratory disease (BRD) continues to be one of the greatest challenges facing cattle producers and managers. Changes in performance and carcass characteristics and economic losses caused by BRD are well documented in the literature (Gifford et al. 2012). From these studies it is clear that there is a substantial decrease in performance by calves diagnosed with BRD. Dry matter intake, average daily gain (ADG), and growth to feed ratio are decreased in majority of the disease cases. The incidence of BRD during finishing results in decreased ADG and final body weight (Gardner et al. 1999). Decreased growth and carcass quality results from inadequate feed intake during times of sickness, or it could be that gene expression and metabolism in economically important tissues are changing priorities. Instead of utilizing nutrients to increase in size, muscle and fat tissue may be repartitioning nutrients toward areas that have a greater demand. This has been observed in human, mouse, and swine models, and more research is needed in cattle (Gifford et al. 2012). In the literature extensive data can be found on the relationship between measures of dietary intake, lung function, and various respiratory disease outcomes, but only few of the studies available have evaluated the association between bovine respiratory disease and changes of haematological and blood biochemistry variables. Infection of the respiratory organs and subsequent inflammation induce acute responses that initiate physiological changes ultimately leading to decreased growth. The acute phase response begins within inflammatory sites, where cells involved in the innate immune response produce and release a vast number of inflammatory mediators, 
among which cytokines play very important roles. Cytokines induce a cascade of events which potentiate the appearance of characteristic clinical changes: fever, anorexia or weight loss (Gabay and Kushner 1999). In addition, cytokines activate receptors on different target cells leading to systemic inflammatory reactions, including hormonal or metabolic, resulting in a number of biochemical changes, such as increased production of adrenocorticotrophic hormone and glucocorticoids, activation of the blood coagulation system, muscle catabolism, leukocytosis, decreased serum concentrations of calcium, zinc, iron, and vitamin A, and changes in liver protein synthesis with changes in the concentrations of some plasma proteins (Gru y s et al. 2005; Cray et al. 2009).

Our results indicate that respiratory diseases and particularly chronic cases not only lead to direct disturbances of the lung function with changes in gas exchange, they also cause changes in the haematological profile. Compared to healthy calves we recorded a significantly higher total number of WBC, concentration of haemoglobin in erythrocytes and difference in the mean number of RBC. Similar results were found in the number of WBC, absolute band neutrophil and monocyte counts, alteration in peripheral blood leukocytes function by Bednarek et al. (1998). The increase of WBC, mainly neutrophils, is a frequent finding in many diseases as a consequence of inflammatory processes like in respiratory diseases in the evaluated sick calves. Differences in haemoglobin concentration and the mean RBC number could be a consequence of adaptation and compensatory processes reflecting chronic pulmonary disease, hypoxaemia and stimulation of erythropoiesis. The results indicate that long-lasting hypoxaemia in calves with chronic respiratory diseases may lead to polycythaemia. Similar findings in calves are also reported by Schulz et al. (1987). Opposite changes in the mean RBC counts, as well as haemoglobin values were reported by Hanzlicek et al. (2010) and Fraser et al. (2014) in experimentally induced acute pneumonia in calves. No changes in the WBC number, lower concentrations of haemoglobin and RBC number were found in calves with chronic pneumonia by Blum et al. (1996).

Alteration of the protein synthesis in calves suffering from respiratory disease was indicated in the present study by significant differences found in the protein profile of calves. Higher total proteins and total immunoglobulins and lower concentrations of albumin were found in sick calves. These changes correspond with the changes described during the acute phase response. Serum albumin is the major negative acute phase protein. During the acute phase response the demand for amino acids for synthesis of the positive acute phase proteins is markedly increased, which necessitates reprioritisation of hepatic protein synthesis. It has been reported that during the acute phase response $30-40 \%$ of hepatic protein anabolic capacity is used for the production of positive acute phase proteins; thus, the production of other proteins needs to be curtailed (Mackiewicz 1997). Albumin has a relatively long half-life, approximately 14-20 days, and because of this, it has been touted as a marker of chronic nutritional status. The acute phase reaction triggers downregulation of albumin production (Gabay and Kushner 1999). Tothova et al. $(2012,2013)$ showed that not only acute diseases of the respiratory tract but also chronic cases are characterised with increased production of some acute phase proteins and significant changes in serum protein profile characterized by hyperproteinaemia, hyperglobulinaemia, hypoalbuminaemia and lower albumin-globulin ratio. The changes in protein profile indicate significant changes in protein synthesis in the liver, which likely modifies amino acid requirements for the animals. Thus acute phase response may have adverse effect on muscle in animals with BRD with consequences on performance, muscle mass and carcass traits (Gifford et al. 2012). The hypermetabolic state that occurs during an illness also results in alteration in carbohydrate and lipid metabolism and causes depletion of carbohydrate stores. Montgomery et al. (2009) observed that heifers treated for apparent BRD had decreased glucose concentrations compared to those that were not 
treated. Blood glucose concentration is one of the biochemical indicators on the basis of which one may draw conclusions pertaining to the body energy supply (Kupczynski and Chudoba-Drozdowska 2002). In our study in sick calves we found significantly lower mean concentration of serum glucose. This may be a result of longer lasting inadequate feed intake and energy supply during times of sickness. Decreased concentrations of glucose were recorded in calves with chronic pneumonia also by Blum et al. (1996) and by Hanzlicek et al. (2010) during experimentally induced pneumonia in calves.

Among the enzymes analysed in our study, significantly higher activity was found in AST and LDH. While the mean values of GGT were not different between groups of calves, the mean CK activity was higher in diseased calves. According to the present knowledge mainly from human medicine, $\mathrm{LDH}$ is one of the potential variables presented in the literature as a possible indicator of lung damage (Drent et al. 1996). Our results correspond with the findings presented in calves suffering from respiratory disease by Nagy et al. (2013). Aspartate aminotransferase originates from many tissues but muscles and liver are considered to be its major sources. Higher activity of AST is not specific to a particular organ, but it is likely to be of muscle origin because of higher CK activity, as well recorded in sick calves probably as a result of increased breathing rate and increased muscle activity in the course of prolonged duration of severe respiratory disease. Elevation of the AST and CK activity was also observed by Abdullah et al. (2013). The elevation of the activity of these enzymes could be due to decreased feed intake and starvation in sick animals, as well as of muscle origin as a consequence of dystrophic damage of muscles during longer lasting recumbency or increased respiratory muscle work in many severe cases of disease. Only few data are available on the effect of respiratory disease on the mineral status, mainly trace elements, in calves. In our study significantly lower mean values were recorded in the serum concentrations of $\mathrm{Mg}, \mathrm{P}, \mathrm{Fe}$, and $\mathrm{Zn}$ in sick calves. Hanzlicek et al. (2010) found evident changes in the concentrations of $\mathrm{K}$ and $\mathrm{Cl}$ (decrease of values), no effect of trial day was found for Na. Fraser et al. (2014) found a significant association with blood sample collection day and a decrease of $\mathrm{Cl}, \mathrm{K}$, and $\mathrm{P}$ concentrations and interactions between blood sample collection day and pneumonia severity in $\mathrm{Ca}$ and $\mathrm{Na}$ concentrations in calves after experimentally induced pneumonia. Significant differences between healthy calves and calves with pneumonia with lower values of $\mathrm{Ca}$ and $\mathrm{K}$ in sick animals were recorded by Ragbetli et al. (2010). Blum et al. (1996) recorded decreased concentrations of blood plasma iron in calves with chronic pneumonia. Changes found in the concentrations of the evaluated minerals are dependent at least to some degree on dietary intake; some of them such as $\mathrm{Na}$ and $\mathrm{Ca}$ are closely regulated by homeostatic systems in the body. In some cases the contents of minerals are likely to be low only when the intake is extremely low. Inappetence and change in feed intake may explain the lower serum concentrations of the evaluated minerals. Decreased appetite may explain the lower serum concentrations of phosphorus and magnesium in calves, both are much more dependent on dietary intake (Rowlands 1980).

Changes found among the evaluated variables in calves affected by respiratory tract disease may be related to the effect of infection and cytokines, and endotoxin-induced sickness behaviour in the form of lethargy, anorexia, adipsia and social interactions with reduced food intake (Dantzer 2001). The negative effect can be more severe in animals with prolonged or multiple episodes of sickness compared to animals that become sick for a short period of time and then recover. Blum et al. (1996) stated that haematological, metabolic, and endocrine changes in calves with chronic pneumonia are the result of expression of reduced energy and protein intake and of nutrient partitioning which contribute to reduced growth performance.

In conclusion, the present results shed further light on the pathophysiology and pathogenesis of respiratory disease in cattle from a metabolic point of view. They 
provide evidence that respiratory disease in calves affects not only the lung function with impairment of gas exchange, but it also has an impact on several other blood constituents. Significant changes compared to clinically healthy animals were recorded in more than half of the analysed variables. Beside the aetiological and symptomatic treatment, in sick animals increased attention should therefore be paid to adequate and proper nutrition for elimination or alleviation of the adverse effects of the disease on the metabolism and functioning of organs. In sick calves it is necessary to monitor feed intake and focus on the supply of sufficient energy, protein and minerals through feed. Parenteral administration of vitamins and minerals may also be beneficial. The diagnostic significance of these results needs further investigation. Future research is warranted to determine the response of individual animals to this disease and to describe the metabolic changes which occur during the course of respiratory diseases.

\section{Acknowledgments:}

This work was supported by VEGA Scientific Grant 1/0154/15 and 1/0447/14 from the Ministry of Education, Slovak Republic.

\section{References}

Abdullah FFJ, Osman AY, Adamu L, Zakaria Z, Abdullah R, Zamri-Saad M, Saharee AA 2013: Haematological and biochemical alterations in calves following infection with Pasteurella multocida Type B: 2, bacterial lipopolysaccharide and outer membrane protein immunogens (OMP). Asian J Anim Vet Adv 8: 806-813

Bednarek D, Zdzisinska B, Kondracki M, Rzeski W, Lokaj I, Kandefer-Szerszen M 1998: Alterations in peripheral blood leukocytes functions during enzootic bronchopneumonia of calves. Effect of treatment with antibiotics and immunomodulators. Deut Tierärztl Woch 105: 194-199

Blum JW, Bruckmaier RM, Moser M 1996: Endocrine, metabolic and hematological changes associated with reduced growth performance during chronic pneumonia in calves: a case study. Deut Tierärztl Woch 103: $115-116$

Coghe J, Uysterpruyst Ch, Bureau F, Van de Weerdt ML, Lekeux P 1999: Preliminary classification of the bovine respiratory complex into different levels of severity. Bovine Pr 33: 85-87

Coghe J, Uysterpruyst Ch, Bureau F, Detilleux J, Art T, Lekeux P 2000: Validation and prognostic value of plasma lactate measurement in bovine respiratory disease. Vet J 160: 139-146

Collie DDS 1992: Pulmonary function changes and clinical findings associated with chronic respiratory disease in calves. Brit Vet J 148: 33-40

Cole N A 1996: Review of bovine respiratory disease: Nutrition and disease interactions. In: Smith R (Ed.) Review of Bovine Respiratory Disease-Schering-Plough Animal Health. Veterinary Learning Systems, Trenton, pp. 57-74

Cray C, Zaias J, Altman NH 2009: Acute phase response in animals: a review. Comparative Med 59: 517-526

Dantzer R 2001: Cytokine-induced sickness behavior: Mechanisms and implications. Ann NY Acad Sci 933: 222-234

Drent M, Cobben NA, Henderson RF, Wouters EF, van Dieijen-Visser M 1996: Usefulness of lactate dehydrogenase and its isoenzymes as indicators of lung damage or inflammation. Eur Respir J 9: 1736-1742

Fraser BC, Anderson DE, White BJ, Miesner MD, Lakritz J, Amrine D, Mosier DA 2014: Associations of various physical and blood analysis variables with experimentally induced Mycoplasma bovis pneumonia in calves. Am J Vet Res 75: 200-207

Gabay C, Kushner I 1999: Acute-phase proteins and other systemic responses to inflammation. New Engl J Med 340: $448-454$

Gardner BA, Dolezal HG, Bryant LK, Owens FN, Smith RA 1999: Health of finishing steers: Efects on performance, carcass traits, and meat tenderness. J Anim Sci 77: 3168-3175

Gifford CA, Holland BP, Mills RL, Maxwell JK, Farney JK, Terrill SJ, Step DL, Richards CJ, Burciaga Robbles LO, Krehbiel CR 2012: Growth and development symposium: Impact of inflammation on cattle growth and carcass merit. J Anim Sci 90: 1438-1451

Gruys E, Toussaint MJM, Niewold TA, Koopmans SJ 2005: Acute phase reaction and acute phase proteins. J Zhejiang Univ - Sc B 6: 1045-1056

Hanzlicek GA, White BJ, Mosier D, Renter DG, Anderson DE 2010: Serial evaluation of physiologic, pathological, and behavioral changes related to disease progression of experimentally induced Mannheimia haemolytica pneumonia in postweaned calves. Am J Vet Res 71: 359-369

Kupczynski R, Chudoba-Drozdowska B 2002: Values of selected biochemical parameters of cows blood during their drying-off and the beginning of lactation. EJPAU Ser Vet Med 5: 225-231 
Lekeux P 1995: Bovine respiratory disease complex: An European perspective. Bovine Pr 29: 71-75

Mackiewicz A 1997: Acute phase proteins and transformed cells. Int Rev Cytol 170: 225-300

Montgomery SP, Sindt JJ, Greenquist MA, Miller WF, Pike JN, Loe ER, Sulpizio MJ, Drouillard JS 2009: Plasma metabolites of receiving heifers and the relationship between apparent bovine respiratory disease, body weight gain, and carcass characteristics. J Anim Sci 87: 328-333

Nagy O, Seidel H, Paulíková I, Mudroň P, Kováč G 2006: Use of blood gases and lactic acid analysis in diagnosis and prognosis of respiratory diseases in calves. Bull Vet Inst Pullawy 50: 149-152

Nagy O, Tóthová Cs, Seidel H, Paulíková I, Kováč G 2013: The effect of respiratory diseases on serum lactate dehydrogenase and its isoenzyme patterns in calves. Polish J Vet Sci 16: 211-218

Ragbetli C, Ceylan E, Tanritanir P 2010: The effect of tulathromycin treatment on biochemical parameters in Montofon calves with pneumonia. Asian J Anim Vet Adv 5: 169-174

Rowlands GJ 1980: A review of variations in the concentrations of metabolites in the blood of beef and dairy cattle associated with physiology, nutrition and disease, with particular reference to the interpretation of metabolic profiles. World Rev Nutr Diet 35: 172-235

Schulz O, Walzel R, Umlauft KD, Blohm H, Liebig F, Claus D 1987: Behavior of some biochemical parameters in calves with pneumonia (in German). Monatsh Veterinärmed 42: 248-251

Slanina L', Beseda I, Hlinka D, Illek J, Kováč G, Kroupová V, Lehocký J, Michna A, Rossow N, Sokol J, Vajda V 1992: The metabolic profile of cattle in relation to health and production (in Slovak). Ústav vedeckých informácií a osvety, Bratislava, pp. 115

Tóthová Cs, Nagy O, Seidel H, Kováč G 2012: The effect of chronic respiratory diseases in calves on the serum protein electrophoretic pattern. Acta Vet Brno 81: 365-370

Tóthová Cs, Nagy O, Kováč G 2013: The serum protein electrophoretic pattern and acute phase proteins concentrations in calves with chronic respiratory diseases. Acta Vet-Beograd 63: 473-486

Wall RE 2001: Respiratory acid-base disorders. Vet Clin N Am-Small 31: 1355-1367

Wittum TE, Woolen NE, Perino LJ, Littledike ET 1996: Relationships among treatment for respiratory tract disease, pulmonary lesions evident at slaughter, and rate of weight gain in feedlot cattle. J Am Vet Med Assoc 209: $814-818$ 